\title{
Impact of Religion on Hindi Personal Names
}

\author{
R.R. MEHROTRA
}

Religion is the mainstay of Hindu society. It is in the fitness of things that the vast majority of Hindi names are derived from Hindu religion, particularly Hindu gods and goddesses, saints and philosophers, sacred rituals and centres of pilgrimage. There is hardly a deity, male or female, of the Hindu pantheon that has not figured in personal names. It is often believed that the mere utterance of the name of a god or goddess works as a spell upon the utterer which not only protects him from the evil spirit but also brings good luck, happiness and prosperity. By naming their children after gods and goddesses, parents and elders in the family hope to gain easy punya (the divine reward of a righteous deed). For, whenever they would be calling or referring to their children, they would be uttering the names of gods/goddess and thereby making them entitled to the punya that accompanies the mere utterance of a divine name. Little wonder therefore if the nomenclature of the Hindus abounds in the names of gods and goddesses. This particular phenomenon has been termed by Bean as "double indexicality" which she explains thus, "the association with the bearer on the one side and the deity on the other and subsequent beliefs about the relationship between deity and bearer derive from the one being named for the other' (Bean 1978: 97). The following Table of personal names presents a galaxy of the Hindu pantheon.

Table 1.

\begin{tabular}{lll}
\hline \multicolumn{1}{c}{ Male Deities } & Female Deities \\
\hline Ram Prasad & Sita \\
Shiva Prasad & Parvati \\
Satya Narain & Laxmi \\
Hanuman Prasad & Durga \\
Ganesh Das & Maya \\
Indra Deo & Bhawani \\
Badri Narain & Shitala \\
Krishna Nath & Saraswati \\
Bhairo Nath & Annapurna \\
Marsingh Das & Siddheshwari
\end{tabular}




$\begin{array}{ll}\text { Surya Das } & \text { Gauri } \\ \text { Salik Ram } & \text { Gayatri } \\ \text { Vishnu Kant } & \text { Kali } \\ \text { Pashupati Nath } & \text { Mangala } \\ \text { Bramha Dev } & \text { Devaki }\end{array}$

According to a survey made by Vibhu the Hindu deities adopted in personal names have been placed in the following order of popularityShiva (10.5\% of total names), Krishna (10.1\%), Ram (6.4\%), Vishnu (5.3\%), Parvati (3.2\%), Ishwar (2.63\%), Surya (1.2\%), Ganesh (.4\%) and Bramha (.62\%), (Vibhu 1958: 68). It is important to note that in the Hindu pantheon a deity is known and worshipped by a number of names including some which are descriptive either of the role or the features that characterize them. Shiva, for instance, has the following names-Shankar, Mahesh, Har, Bhola, Shambhu, Mahadev. Some of the common descriptive names of Shiva are Chandrabhal (one who holds the moon on one's forehead), Jatadhar (one wearing matted hair rolled up), Mrityunjaya (one who conquers death), Uma Nath (one who is the spouse of Uma), Trilochan (one with three eyes), Neelkanth (one whose neck is bluish), Digambar (the naked), Bhut Nath (the patron of ghosts and evil spirits). All these have figured in personal names.

In their enthusiasm for having their children named after a deity, the devout Hindus tend to believe that any word can be bracketed with a deity's name even if it does not make any sense. Ram's name, for instance, when borrowed to form personal names has been subjected to such formations as Ram Cheej (thing), Ram Daur (run), Ram Vriksha (tree), Ram Tanik (a bit), Ram Rekha (line), Ram Sagar (ocean), Ram Nishthur (ruthless), Ram Talika (list), Ram Acharaj (surprise), Ram Kathin (difficult), Ram Tahal (walk), Ram Badal (change), Ram Dwar (door), Ram Sarovar (lake), Ram Hunkar (roaring), Ram Baraf(ice). The coupling of Ram with odd objects and activities without caring for their collocability suggests the element of religious bias in the matter relating to personal names.

Names of divinity when borrowed for personal names generally tend to follow one of the following patterns:

1. By adding Prasad, Dutta, Din or Baksh to the name of the deity. When a child is born presumably as a result of the blessings of or vow made to a god or goddess, he is believed to be a gift from that particular deity. Hence he gets a name which denotes this fact-i.e. Hanuman Prasad (gift from Hanuman), Ram Bakash (blessing from Ram), Durga Dutta (provided by Durga), Bhagwan Din (provided by Bhagwan). 
2. Another popular practice is for a boy to be named as the Das (slave) or Sevak (servant) of some god or goddess such as Krishna Das, Ram Sewak. Names of girls are not formed in this fashion.

3. By combining names of two deities such as Ram Shankar, Hari Har, Shiva Gopal. Sometimes the name of a male deity is combined with that of a spouse, the latter invariably appearing first in the name, i.e., Sita Ram, Radha Krishna, Lexmi Narain, Gauri Shankar.

4. By adding a term denoting kinship. Normally only two kin terms are used with the name of deity, the first being a spouse (husband/wife) and the second being a progeny (son/daughter). Names of the former type are Kamala Pati, Gauri Nath, Radha Vallabh, Siya Var. Names of the latter type are Devaki Nandan, Pavan Sut, Janak Nandini.

Like gods and goddesses Hindu saints and philosophers have figured liberally in Hindi names. The following Table of some popular Hindi names brings to focus a distinguished congregation of saintly people drawn from different periods of time.

Table 2 .

\begin{tabular}{ll}
\hline Bhrigu Nath & Gorakh Nath \\
Ambarish & Byas Muni \\
Atri Dev & Kapil Dev \\
Dadhichi & Durwasa \\
Patanjali & Dhruwa Kumar \\
Bharadwaj & Vashistha Narain \\
Valmiki & Vishwamitra \\
Suniti Kumar & Eknath \\
Tulsi Das & Gautam \\
Ram Krishna & Ballabh Das \\
\hline
\end{tabular}

The names of various centres of Hindu pilgrimage have also been exploited for the purpose of forming personal names in Hindi. There is hardly a town noted for its sacred associations that has not become a popular personal name. Some illustrations are as follows:

Table 3.

$\begin{array}{ll}\text { Kashi Nath } & \text { Gokul Das } \\ \text { Banarasi Das } & \text { Vindhyavasani Prasad } \\ \text { Badri Narain } & \text { Kailash Nath } \\ \text { Ayodhya Prasad } & \text { Dwarika Prasad } \\ \text { Brindavan Lal } & \text { Gangotri Prasad } \\ \text { Prayag Lal } & \text { Hrishikesh }\end{array}$


Similarly, objects used in ritual worship have also been used to form names of people, i.e., Kalash (holy pitcher), Narain, Deep (the earthen lamp) Narain, Phool (flower) Dev, Shami (a sacred tree) Chand, Kapur (camphor) Chand.

In orthodox Hindu families it is customary to seek the advice of an astrologer who suggests the first letter of a child's name after studying the planetary condition in which it was born. For instance, if the child is born in Ashwini Nakshatra, it will get a name beginning with the letter che i.e. Cheta, Chet Ram, Chetkar, Chela. Sometimes, children get their names from planets and the signs of the zodiac that were active at the time of their birth as will be evident from the following Table.

Table 4 .

\begin{tabular}{ll}
\hline Swati Dutta & Ashwini Prasad \\
Mekh Chand & Kumbha Nath \\
Tula Ram & Mool Shankar \\
Tisya Dutta & Rohini Prasad \\
Mithun Singh & Hasti Mal \\
\hline
\end{tabular}

The impact of the forces of modernization in our time has led to the curbing of the tendency of naming one's children after gods and saints, rituals, and other religious performances. The influence of new values and ideologies of modern urban civilization, education, secular and democratic thinking, press, cinema, T.V. and other means of mass communication have resulted in a strong tendency in favor of secular names which highlight some abstract qualities or attributes in preference to the age-old names of gods and goddesses. The following Table contains some names of this type.

Table 5. Secular Names

\begin{tabular}{ll}
\hline \multicolumn{1}{c}{ Males } & \multicolumn{1}{c}{ Females } \\
\hline Navin (Novel, new) & Rekha (Line) \\
Vinod (Amusement) & Jyoti (Light) \\
Vikas (Growth) & Nutan (New) \\
Sharad (Autumn) & Kalpana (Imagination) \\
Prem (Love) & Sumati (Unity) \\
Santosh (Satisfaction) & Chhaya (Shadow) \\
Anand (Bliss) & Karuna (Compassion) \\
Daksh (Efficient) & Sadhana (Devotion) \\
Vinay (Politeness) & Mamta (Affection) \\
Pramod (Rejoicing) & Bumati \\
\hline
\end{tabular}


These names do not give any hint as to the religious leanings and caste affiliations of the persons bearing these names and the elders who assigned the names. Such a tendency is on the increase day by day. This incidentally supports the hypothesis developed by Paul Kay that the increasing complexity and diversity within a speech community tends to produce a more autonomous and context-free language, the trend being "from a non-autonomous to an autonomous system of communication" (Kay 1977: 24).

Benaras Hindu University

\section{REFERENCES}

Bean, Susan S. (1978). Symbolic and Pragmatic Semantics: A Kannada System of Address. Chicago.

Kay, Paul (1977). Language evolution and speech style. In Ben G. Blount and Mary Sanches (eds.). Sociocultural Dimensions of Language Change. New York.

Vibhu, Vidyabhushan (1958). Abhidhan Anushilan (In Hindi). Allahabad.

* * * *

Starting about 1590, in the reign of Elizabeth I, the more fanatical Puritans began to baptize their children by scriptural phrases, pious ejaculations, and goldly admonitions. The Presbyterian clergy baptized with such names as Stedfast, Renewed, Safe-on-Highe, Much-Merceye, Increased, Accepted, and Thankful. Some of the more extreme, not to say colorful, are Search-theScriptures, Job-rakt-out-of-the-Ashes, Zeal-of-the-land, Help-on-high, Flie-fornication, and Sorry-for-sin. Best known is Praise-God Barebone whose name is associated with the Barebones Parliament of 1653.

Elsdon E. Smith, Treasury of Name Lore (1967), p. 190. 